\title{
Faecal Sludge Management in Botswana: A Review of Current Practices and Policies Using the Case of Gaborone Low Income Areas
}

\author{
Phillimon T. Odirile ${ }^{1 *}$, Innocent Thukwi1, Ontiretse Dintwa1, Bontle Mbongwe² \\ ${ }^{1}$ Department of Civil Engineering, University of Botswana, Gaborone, Botswana \\ ${ }^{2}$ Department of Environmental Health, Faculty of Health Sciences, University of Botswana, Gaborone, Botswana \\ Email: *odirilep@mopipi.ub.bw
}

How to cite this paper: Odirile, P.T., Thukwi, I., Dintwa, O. and Mbongwe, B. (2018) Faecal Sludge Management in Botswana: A Review of Current Practices and Policies Using the Case of Gaborone Low Income Areas. Journal of Environmental Protection, 9, 122-139.

https://doi.org/10.4236/jep.2018.92010

Received: December 28, 2017

Accepted: February 23, 2018

Published: February 26, 2018

Copyright $\odot 2018$ by authors and Scientific Research Publishing Inc. This work is licensed under the Creative Commons Attribution International License (CC BY 4.0).

http://creativecommons.org/licenses/by/4.0/

cC) (7) Open Access

\begin{abstract}
In the past sanitation was the responsibility of Local Authorities or councils with the Department of Waste Management and Pollution Control (DWMPC). Pollution of groundwater in Botswana is currently forcing the Government of Botswana (GoB) to abandon pit latrine construction and Ventilated Improved Pit (VIP) emptying services in peri-urban areas. Currently Government has embarked on the expensive and unsustainable construction of sewer systems that require peri-urban communities to pay for connection fees. Most rural communities cannot afford these fees and since Botswana is a water scarce country, sewer connection may be costly for the country. This paper aims to review current practices, policies and challenges facing Botswana in Faecal Sludge Management (FSM). A desktop review was carried out to review policies, regulations, guidelines and strategies on waste management. A pretested questionnaire was administered among 50 randomly selected households to assess current practices in sludge management from two suburbs in Gaborone. Key informant interviews were undertaken among water and sanitation stakeholders to establish roles on waste management and faecal sludge management. Despite the disjointed efforts by stakeholders, Botswana has the potential to improve the FSM in the country. Though unsafe, FSM/pit emptying has the potential to provide income and employment to both the rural and urban poor and making it safe may have wider economic benefits.
\end{abstract}

\section{Keywords}

VIP Latrine, Faecal Sludge Management, Sanitation, Sludge Management Policy 


\section{Introduction}

The launching of National Rural Sanitation Programme (NRSP) during National Development Plan 7 (NDP 7) (1991-1997) saw a rapid increase in the provision of both conventional and improved pit latrines in the rural households of Botswana. There has been an extensive local development of different types of latrines such as the Ventilated Improved Pit Latrine (VIP) in Botswana. While the latrines have improved the sanitation, by providing dignity to the rural poor, they have, in some areas, led to deterioration of the groundwater quality by bacterial pollution and by increasing the nitrate content [1] [2] [3] [4]. Therefore, for effective operations of such facilities, proper construction and maintenance is key. Some latrines are designed to be emptied regularly while most latrines are just pits which are abandoned once they are filled up. However, the deterioration of the quality of groundwater resources in some parts of Botswana has led to the development of a National Policy on Wastewater and Sanitation which requires that all on-site sanitation technologies used in the country, must be able to satisfy the following criteria; 1) Operational effectiveness and reliability of technology, 2) Minimal public health risks to the users, 3) Cultural and social acceptance, 4) Affordability, 5) Free from offensive smell and unsightly conditions, 6) Inability to attract flies and other insects, 7) Minimal groundwater pollution risks, 8) Minimal water usage and Easy maintenance by the user. The VIP latrine has been found to comply with most of the criteria mentioned but criteria number 7 , while it is suspect with regard to criteria number 2 . However, the issue of pit emptying and the issue of sludge management after emptying are over looked in this policy. In technical terms, models of the VIP latrine have been developed which satisfy most of the generally established criteria for acceptable on-site sanitation systems. These are regarded to be more socially and culturally acceptable to users; structurally and functionally sound; and sanitary.

Faecal Sludge Management (FSM) can provide jobs to the community and reduce unemployment. Thus in Sanitation terms, people in rural areas suffer from lack of sanitation facilities such as proper toilets facilities. Whenever there is access to sanitation, a major problem that arises in densely populated areas where pit latrines are the main type of sanitation systems is nitrate pollution of the groundwater [5]. In this paper, faecal sludge (FS) is used interchangeably with Pit latrine sludge which a material that is contained Pit latrines, and has not been transported through a sewer. Faecal sludge therefore, comprises all liquid and semi-liquid contents of pits accumulating in public and private latrines or toilets (VIP installations).

Household habits influence the material composition of pit sludge and these materials are largely made up of degradable materials [6] and they influence the characteristics of the faecal sludge and filling, smell and nuisance [7]. In rural areas where there is no waterborne sanitation, defecation is either carried out in the bush, or using pit latrines. The main aim of this paper is therefore to determine the status of FSM and FSM practices in Botswana and to assess whether 
there are any policies to influence FSM.

\section{The Study Area}

Botswana is a landlocked country bordered by Namibia to the west, Zambia to the north, Zimbabwe to the north east and South Africa to the south. This study was carried out in the Gaborone City in Mogoditshane and Broardhurst. The two areas represent rural peri-urban setups of Gaborone city. Gaborone is the capital and largest city of Botswana with a population of 231,626 based on the 2011 census, about $10 \%$ of the total population of Botswana [8]. The latitude and longitude Gaborone city, is $24^{\circ} 40^{\prime}$ South and $25^{\circ} 55^{\prime}$ East. The FS sludge from these areas is core treated with municipal wastewater at the Gaborone Wastewater Treatment plant about $10 \mathrm{~km}$ northeast of Gaborone City.

Lack of income (attributed to lack of employment, insufficient income earning opportunities and the low potential of traditional agriculture) is considered the major and immediate cause of poverty and poor health. Major economic activities for residents in the study area are wholesale and retail trade, construction and manufacturing respectively [8] with government being the main source of employment. Migration from villages to Gaborone City results in overcrowding in low-income communities around Gaborone [9]. Due to lack of proper sanitation, overcrowding may lead to various environmental ailments [9].

\section{Methodology}

A desktop study was undertaken to review regulations and policies relevant to the FSM practices in Botswana. A survey of sanitation stakeholders was conducted between July 2015 and July 2016 in order to understand the roles played by various stakeholders and challenges they face in FSM. Field surveys involving the use of a questionnaire, field observations and photographing were undertaken in 50 randomly selected households from Mogoditshane and Broadhurst suburbs. The two localities were chosen on the bases that, one (Mogoditshane) has a rural setup while the other (Broadhurst) has a peri-urban setup. In addition, private collection and transport businesses that empty the FS with vacuum trucks from pit latrines and transport it to the treatment facilities and Water Utilities Corporation (WUC) staff responsible for operation and maintenance of on-site sanitation and also the FSTP were interviewed. All the 50 studied households responded to the questionnaire and data analysis of community questionnaires was done using Statistical Package for Social Scientists (SPSS version 20) software package. Frequencies, rates and proportions were obtained.

\section{Results and Discussions}

\subsection{Access to Improved Sanitation Technologies}

Provision or improvement of sanitation facilities in Botswana has always been driven by the need to protect the environment and public health. Botswana is doing well in sanitation provision as evidenced by a generally steady increase in 


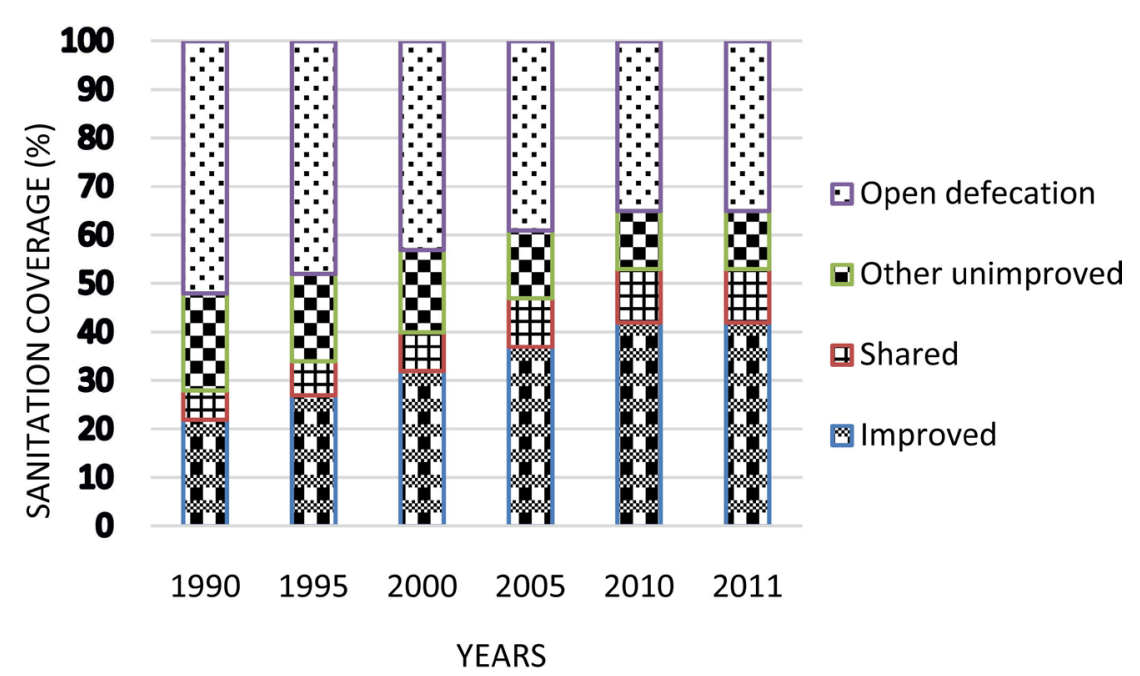

Figure 1. Sanitation provision trends in rural Botswana [11].

sanitation access (Figure 1). This increase is attributable to the fact that, the government has since the 1970s through various policy documents attempted to introduce different sanitation technologies. The increase can also be pointed to Government commitment to international treaties such as the UN Millennium Development Goals (MDGs), now known as Sustainable Development Goals (SDGs). A World Bank report [10] indicates occurrence of rapid urbanisation across cities in the developing world with most of the growth in informal or slum areas. This scenario is also true in Botswana as more and more people migrate to urban cities to look for jobs. This places a strain on water supply and sanitation services due to increased demands as well as formidable obstacles, oftentimes from policy constraints, in meeting this growing demand.

Pit latrines are on-site sanitation systems designed for accumulation and stabilization of faecal matter, urine and sometimes, other materials added to the system over a certain period of time [12]. Pit latrines are the most common forms of sanitation in rural/low cost areas of Botswana. However, there is clearly a disparity in provision of sanitation between rural and urban populations where, about $38 \%$ of the rural population still practiced open defecation in 2010 and almost $40 \%$ of the population, at the national level, only has access to unimproved sanitation/open defecation [13]. This can be clearly observed in Figure 2 indicating that rural population is still greatly exposed to diseases due to possible contact with human excreta.

Although pit latrines are associated with nitrate pollution of the groundwater, [14] has warned against the dangers of exaggerating this problem. The relevance of onsite sanitation to nitrate pollution have been studied and confirmed by various reports in Botswana [15] where, a tentative nitrogen budget is established for pit latrines in eastern Botswana. The Botswana Government strongly believes that everyone has a right to access to clean and affordable water and improved sanitation facilities [16]. This has been shown by the improved sanitation infrastructure provided and subsidised by Government. Figure 3 therefore 


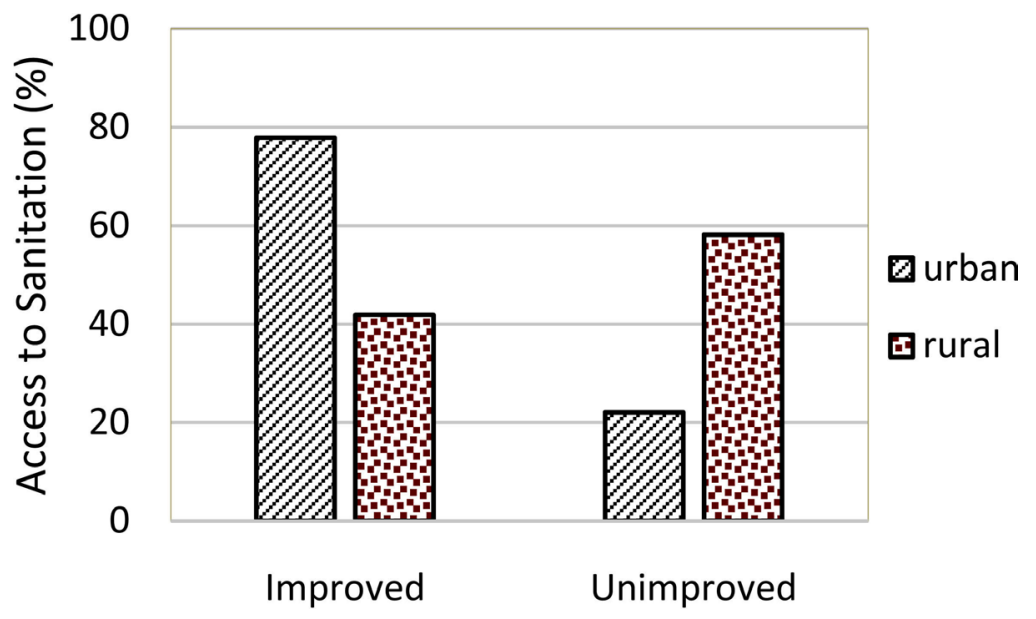

Figure 2. Access to sanitation in urban/rural setup (\%).

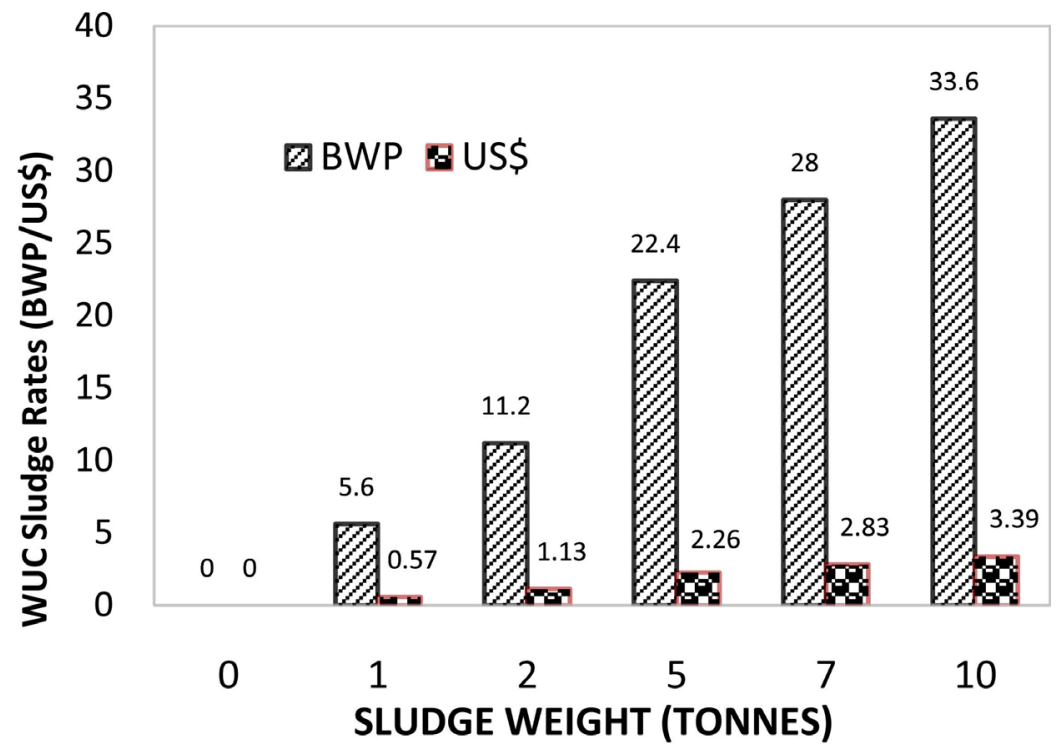

Figure 3. Example cost of sludge per ton of processed sludge (BWP = Botswana pula).

shows the cost of sludge per tonne truck in Gaborone in local currency and US dollar. These cheap prices clearly are meant to encourage the public to reuse in order to ensure there is less amount accumulating.

Government of Botswana (GoB) has been engaged in the exercise of Water Reforms through which the sanitation sector has been shifted from Local $\mathrm{Au}$ thorities (Councils) to the Water Utilities Corporation (WUC). The implementation of the Water Reforms has since met some challenges. Previously, the focus in sanitation has been the provision of infrastructure such as pit latrines by subsidising costs to households in urban areas, through an Urban Sanitation Research Project (USRP) in 1971 with the aim to improve the poor sanitary conditions in growing towns and cities. As a result, there is no proper faecal sludge management (FSM) strategy which poses serious public health and environmental challenges. A solution for effective and sustainable FSM presents a significant global need. 


\subsection{Sludge Management Practices in Gaborone}

Generally, Pit latrines are used for storage of the digested faeces, and are designed primarily for the storage of the digested solids [17] [18]. At present, the predominant form of sanitation in peri-urban Gaborone is the pit latrine/VIP and the Flush toilet, especially in the low-income section of the community. The current and general on-site sanitation management involves a chain of services that include infrastructural provision (toilet facilities); pit emptying; sludge transport; and final disposal, treatment or reuse of sludge (Figure 4).

The Ventilated Improved Pit (VIP) toilet has been described by the Botswana Building Control Act (2007) as:

"a permanent place for decomposition of human waste being a lined or unlined pit, depending on soil conditions, not utilizing water for disposal, and provided with a screened vent to reduce odour and insect nuisance and a squatting platform constructed from impervious and durable materials, and with a pit volume of at least 10 cubic metres to service a maximum of 8 habitable rooms".

VIPs have been proven elsewhere that, when correctly designed, operated and maintained, it can be an acceptable, cost-effective, hygienic and environmentally friendly sanitation system. However, the challenges still remain poor access to, and poor O\&M of existing sanitation systems both contribute to environmental degradation, inefficient pit emptying process which was usually done by councils and is the responsibility of WUC. [19] [20] have reported that, Pit emptying constitutes a major problem in many places, both technically and managerially [19] [20].

The government has been investing a lot on a number of alternative on-site sanitation technologies and has been developed and introduced in Botswana to address the challenges mentioned above such as ecological sanitation (eco-san) technologies. The communities however, still prefer a flush toilet or VIP latrines, due to poor performance of eco-san technologies and that it takes longer before it fills up (at least 2 to 5 years) depending on usage. As in most countries [21], when a pit latrine is full, in Botswana there are also two distinct options: 1) stop using it and construct a new latrine; or 2) empty it.

\subsection{Sludge Collection and Transportation Methods}

There are inconsistencies in designs of VIP latrine throughout the country due

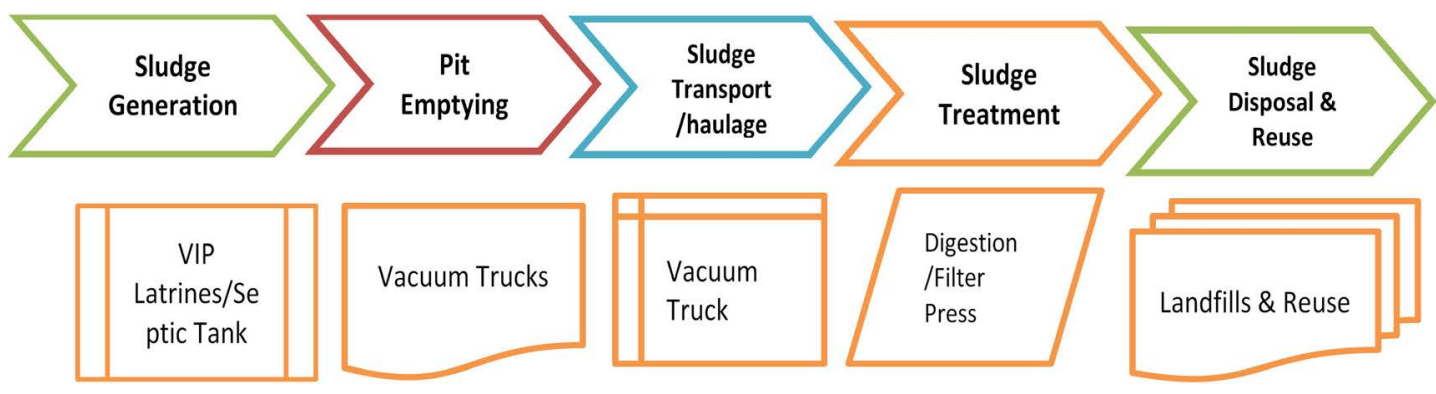

Figure 4. Framework of faecal sludge management practices in Botswana. 
to no availability of standards. The existing VIP construction manual [22] is not available to the community, private companies or even to service providers. This manual was originally intended for use as a field guide for SHHA and NRSP Programme. The toilets are serviced by vacuum pump trucks (Figure 5) which transport faecal sludge to a dumping pond or to a treatment plant while some full pits are abandoned due to either, unavailability of service truck or poor economic status and lack of treatment sites in other areas across the country. According to the interview with the department of Waste Management and Pollution Control (DWMPC), some of the pit latrines were not designed according to the originally prescribed design i.e., without properly lining the pit. This is sometimes the reason why they abandon the pits and build new ones because vacuuming the pit will cause the pit wall to collapse. The discussion with the DWMPC also revealed that, the unlined pit latrines cannot be emptied especially using the vacuum tanks because the pit walls tend to collapse due to swelling. This is the reason why some companies are not willing to service unlined pits.

The pits studied in this work are around Gaborone service area. Mogoditshane VIP Pits are generally deep as compared to Broadhurst whose depth is around 1.83 and $1.37 \mathrm{~m}$ on average respectively. Mogoditshane pits are constructed by individuals (plot owners) while Broadhurst pits were constructed by government under the SHHA and NRSP programmes, hence Mogoditshane depths are greatly variable with the minimum and maximum depths between 1.3 and $2.8 \mathrm{~m}$. Broardhurst pits are mostly at average depths of $1.37 \mathrm{~m}$ with minimum and maximum depths between 1.0 and $2.2 \mathrm{~m}$ respectively suggesting more standardised pit dimensions. These depths are therefore the effective depths for a vacuum tanker to lift sludge during emptying [21] [23]. The reason why the Broadhurst Pits seem standardised, is because the Manual discussed earlier was used for their construction while in Mogoditshane it was not used. The ability of the vacuum tank also depends on the density and viscosity of the sludge as well as the height of the tank above the ground [23].

The over two tons Vacuum tanker (BREVAC-type machinery) is the only type of sludge transport system used in Botswana (Figure 5) and the operations and Maintenance to carry out repairs are usually a challenge and concern for the

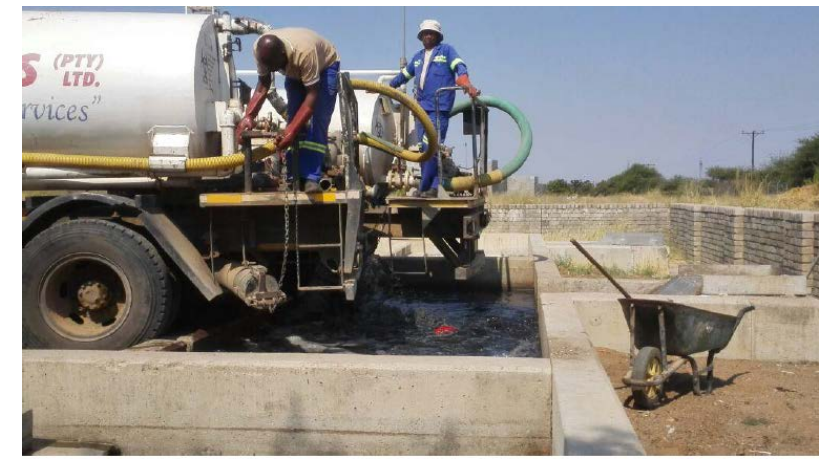

Figure 5. Example private vacuum track discharging at the Gaborone wastewater treatment plant (GWWTP) discharge bay. 
operators. The service period for vacuum trucks is usually very long due to the outsourcing of such services. This practice has a negative effect as it contributes to reduction of the reliability and effectiveness of the emptying practice and also shortens the filling up rate of pits and affects the operations of vacuum tank during emptying. Previously, pit latrines in each area were to be emptied every five years on a rotating basis and the use of BREVAC-type machinery for rural pit emptying is not considered a viable option. As reported in the past, apart from faecal sludge having different densities [18], the authors have also observed solid particles, wood, stones, and plastics in pits which are the major cause of vacuum tank failures during emptying. Figure 6 shows the trends in vacuum truck deliveries of both septic tank and VIP sludge to Gaborone Wastewater Treatment Plant (GWTP). The date indicates that in December period most company are closed for festive season and in January, the service is more than doubled.

Water Utilities Corporation (WUC) has inherited the emptying process from the Gaborone City Council (GCC) and currently operates a fleet of about 3 vacuum trucks of 7, 8 and $10 \mathrm{~m}^{3}$ in volume for the Gaborone service area. The Gaborone service area has an average radius of about $40 \mathrm{~km}$ and includes Gaborone city and the surrounding villages. Each truck services about 7 to 8 pit latrines a day. From Figure 6, it is observed that there are about 582.6 truck deliveries per year of which about $29 \%$ (166) are from pit latrines and $71 \%$ (416) are from septic tanks. When emptying the FS from onsite systems, a number of tasks are performed in accomplishing the job. These tasks include; 1) first the customers does the payment for emptying at the WUC payment centre, 2) the payment centre then passes information to the operations unit who informs the customers and the customer is required to prepare the latrine for emptying, usually by adding water and stirring the pit contents. Ideally, a typical job requires the service provider to respond timeously for emptying. However, WUC has a response time of about 2 months. According to WUC this delayed period is attributed to a

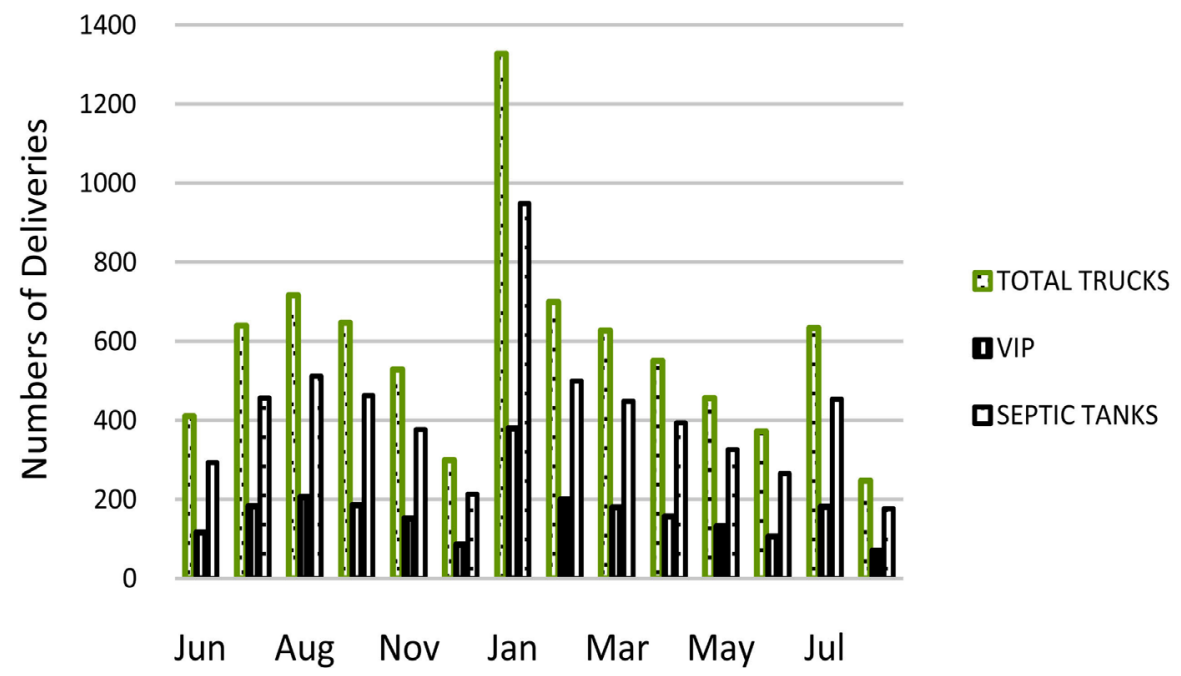

Figure 6. Vacuum truck deliveries of septic tank and pit latrine sludge to GWWTP. 
number of challenges that include; 1) shortage of vacuum truck, 2) communication lapse with customers (public) due to loss of direction by truck drivers caused by lack of street numbering (no plot numbers), and 3) also because of information lapse from the payment centres to operation centres of WUC. Some factors that affect the wide variability of FS characteristics have been observed to include the range of different onsite technologies used, the way in which the system is used, the storage duration (filling rates and collection frequencies), inflow and infiltration, and the local climate. All of these factors should be taken into account when determining FS characteristics.

\subsection{Pit Latrine Usage}

The level of usage of pit latrines is largely dependent of the household occupants. By virtue of the areas' proximity to the city, the community in the two areas relies mainly on renting rooms to the low income community. Therefore, most of plots are multi residential where each plot accommodates multi families. Since the main sanitation is VIP latrines, it is observed that, these latrines are heavily utilized. Figure 7(a) shows that in Mogoditshane, pit latrines usage is about 16 users/latrine/day on average, with a maximum of 56 users/latrine/day. However, the numbers in Broadhurst (Figure 7(b)) are lower than those in Mogoditshane with usage of 10 users/latrine/day and maximum of 17 users/latrine/day.

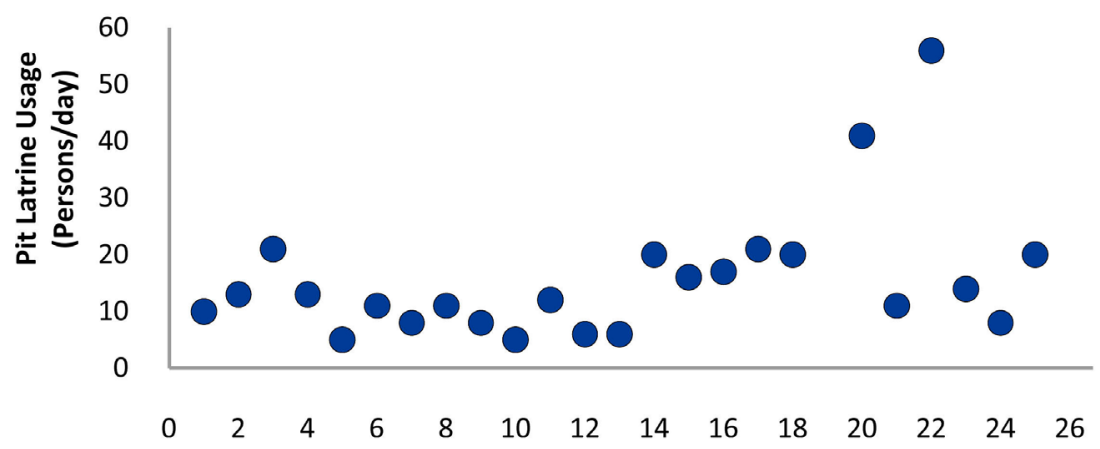

(a)

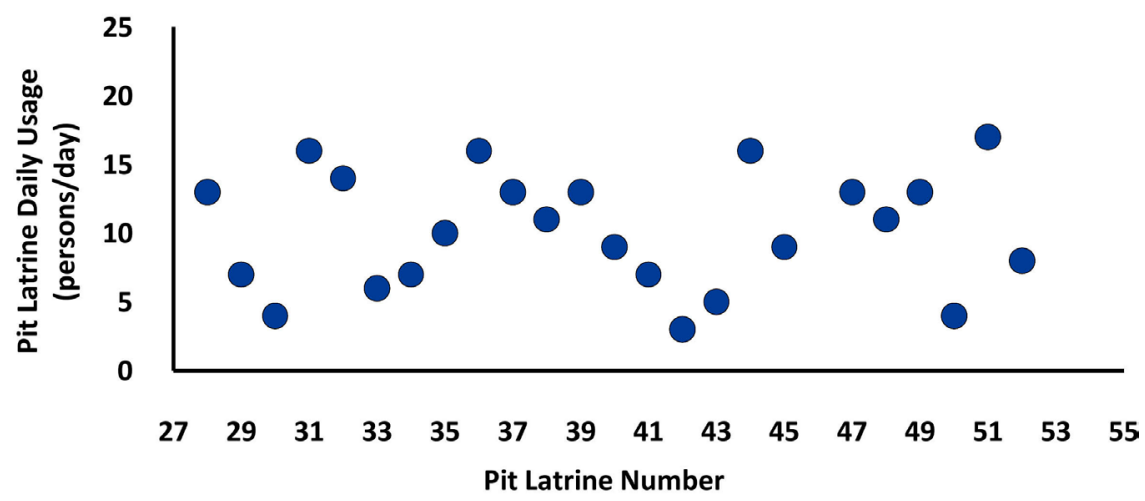

(b)

Figure 7. Number of people using pit latrine per household daily in (a) Mogoditshane and (b) Broahurst. 
Among all the 50 households surveyed, about $84 \%$ and more than $74 \%$ admitted to adding wash water and detergents (such as Jeyes, Domestos and Jik) respectively. According to those interviewed, the reason for addition of such materials in to the pits are for the purposes of cleaning, killing germs and removing odour. Other materials that households admit to throwing into the pit include; obsolete medicine (14\%), pills and sanitary pads or condoms and nappies (26.6\%). This practice can negatively affect the FS and bacterial activity in the pit [12].

\subsection{Environmental and Health Concerns}

The manner in which pits have been constructed have raised concerns that pit latrines may cause various environmental and public health problems such as human and ecological health impacts associated with microbiological and chemical contamination of groundwater due to lack a physical barrier. This results in pollution due to stored FS (excreta) and soil and/or groundwater mixing [24]. Accordingly, the leaching of contaminants from pit-latrine sludge into groundwater is potential threat to human health through well-water contamination. Proximity to pollution sources, including pit latrines have been associated with groundwater nitrate concentrations, including pit latrines, in many countries including Senegal and South Africa [25] [26]. In Botswana, protection of environment and public health is paramount in deciding on the sanitation technology. However, resource recovery from treatment products should be considered as a treatment goal whenever possible, but the number one goal is obviously the protection of the environment and public health. Like in many lowand middle-income countries, regulations for the end-use of sludge do not exist and/or are not enforced in Botswana. In the apparent lack of a regulatory environment, the required levels of treatment become a societal decision as the public decide on what to use the sludge for. The other, concern involves the personnel involved in desludging process as most admit to floating safety measures despite extensive training and protective clothing provided to them.

\subsection{Institutional Arrangement for FSM}

By definition, institutional arrangements refer to the mechanisms by which different government and nongovernmental agencies and private-sector organizations can work together to achieve sustainable FSM [27]. This arrangement is depicted in Figure 8. In the past, sanitation issues were held under the Ministry of Local Government coordinated by the Department of Waste Management and Pollution Control (DWMPC) with councils providing services to the community. This department was later transferred to the Ministry of Environment, Wildlife and Tourism. The DWMPC through the National Rural Sanitation Programme (NRSP) provided assistance to communities by constructing 7000 VIP substructures in various districts. Since the introduction of the Water sector reforms, the infrastructure development of on-site sanitation facilities (VIP) was 


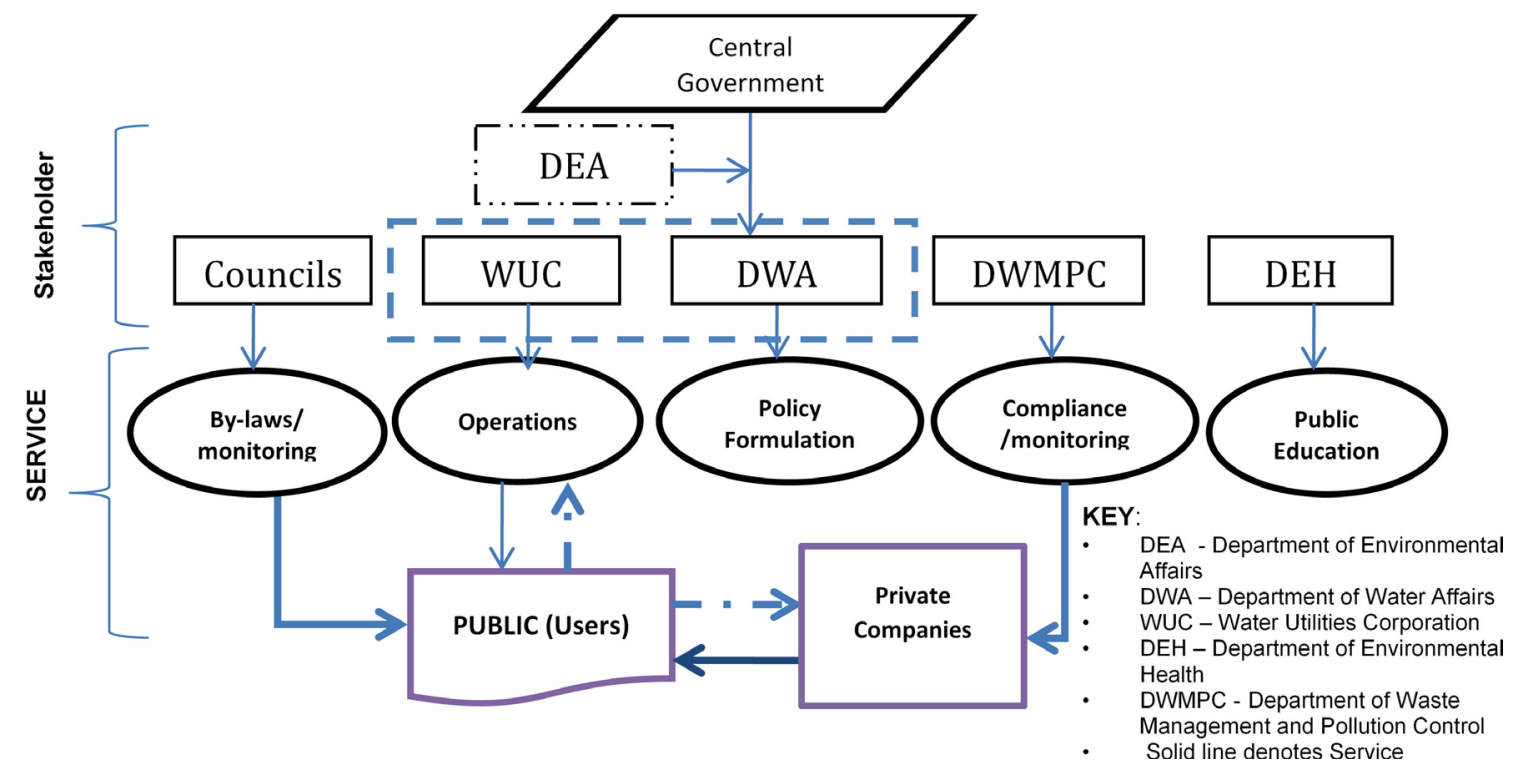

Figure 8. Stakeholders arrangement for faecal sludge management. Broken arrows reflect monitory exchange.

not being coordinated with wastewater service provision.

\subsection{The Role and Responsibilities of Stakeholders}

In the past Councils through the water and waste water department is also responsible for collection of waste from on-site sanitation facilities such as septic tanks, cesspools and pit latrines through the use of vacuum tankers at a nominal fee $(50$ pula $=$ US\$ 5.40). Like it is the case elsewhere [28], the assessment revealed that, the roles and relationships of the stakeholders who are concerned with all aspects of faecal sludge management are not clearly defined. Also the responsibilities between WUC and local authorities are not clearly formulated. These unclear roles of the stakeholders clearly result in duplication of roles and strains relationships that exist among the partners and the resultant effect is usually low quality of service.

The Ministry of Health $(\mathrm{MoH})$ now known as the Ministry of Health and Wellness ( $\mathrm{MoH} \& \mathrm{~W})$ has always been actively involvement in on-site sanitation through Environmental Health Unit, now Division of Environmental and Occupational Health. They have a general brief in relation to environmental health, including human waste disposal. At the local level, both urban and rural councils have Environmental Health Departments, which played an important role in approving and coordinating all on-site sanitation activities within their areas of jurisdiction. These departments also enforce both Solid Waste Management Act and Public Health Act. According to Waste Management Act, the carrier waste has to be registered with the Department of Waste Management and Pollution Control to be able to transport controlled waste within Botswana or across the country (Figure 8). Waste disposal sites and waste management facilities must be registered with the Department of Waste Management and Pollution Control to be allowed to handle controlled waste. The main hindrance to enforcement of 


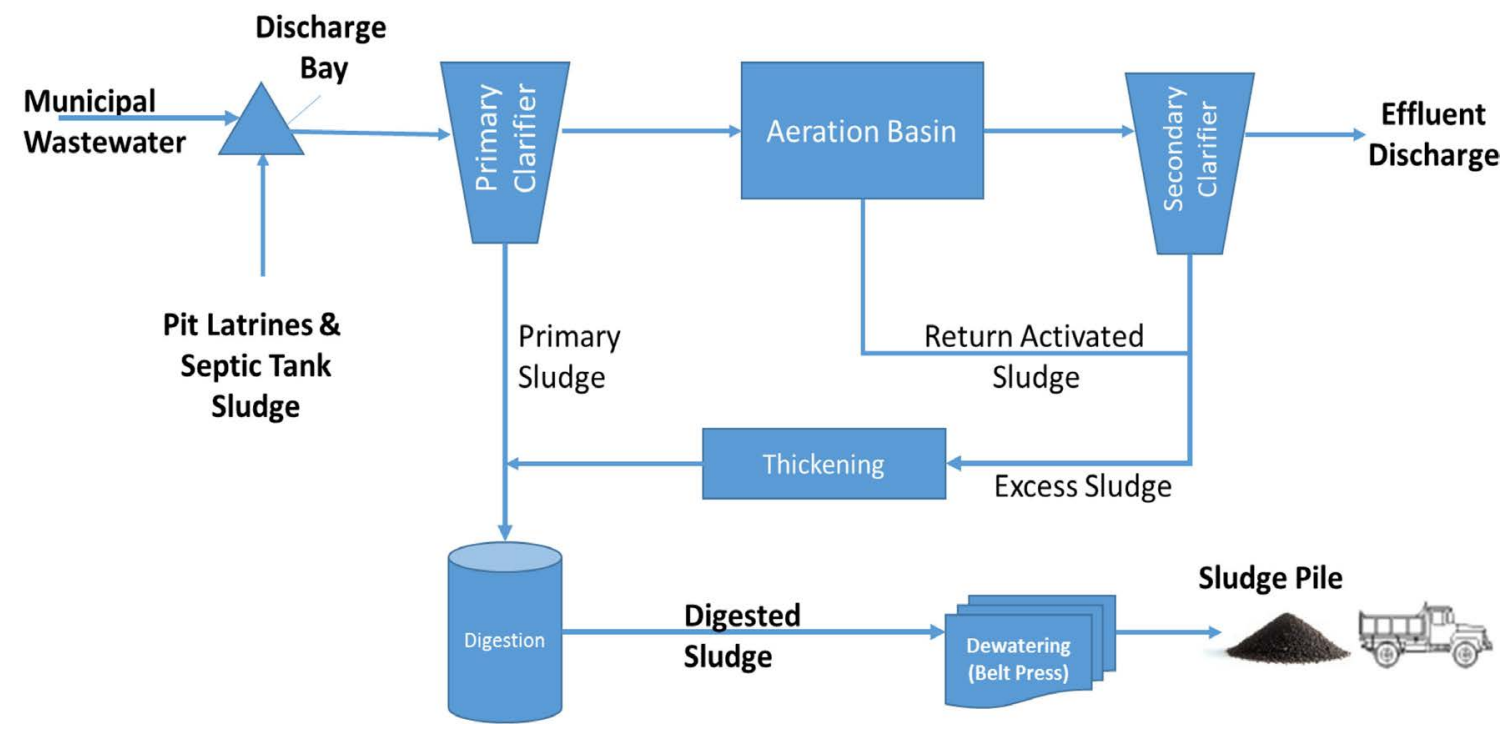

Figure 9. Pit latrine (PL) and septic tank (ST) Sludge mixed with municipal wastewater and co-treated through activated sludge process in Gaborone.

such act is the leniency of charges. Due to limited proper methods of treatment and disposal of FS from pit latrines, sludge management has become an integral part of the wastewater treatment plants across the country (Figure 9). This practice has caused the wastewater treatment plant to malfunction due solids over load.

Application of sludge (a residue of organic and inorganic solids) for agricultural purposes is also emerging as an economically and environmentally acceptable alternative to disposal through landfill and incineration [29] [30] because of the agronomic benefits associated with it [31] [32].

Currently the number one goal of sludge treatment at wastewater treatment plant is the protection of public health. However, it is important to consider resource safe recovery from treatment products as a treatment goal whenever possible. This can be achieved by putting value into the entire process of sludge management. The promotion of safe recovery and reuse of liquid and solid waste is an important strategy for working towards the United Nation's Sustainable Development Goals (SDGs) [33]. Research by [34], reports the success of some waste based resource recovery Business models at Kampala, Uganda; Hanoi, Vietnam; Bangalore, India and Lima, Peru. The success of these business models is attributed to the fact that markets for faecal sludge became competitive that farmers were buying in bulk and drying at their farms.

Because the distance between households and the Treatment plant may be great, then for places far from the WWTP, transfer of faecal sludge from household level can take place by discharging into a transfer stations or permanent or semi-permanent structures [35].

\subsection{The Role of the Private Sector}

In the past, it was the responsibility of the Councils to provide and manage all onsite sanitation facilities to the community. Since construction of these facili- 
ties was over whelming for the councils, that responsibility was outsourced by the councils from the private sector. Therefore, during the NRSP programme, it was the responsibility of government to hire the private individual private-sector builders (usually small building companies or individuals) to construct the pit latrine substructure while the plot owners would then contract the same builder to construct the superstructure under the guidance of a technical assistant from the council. Generally, the latrines are all built by private-sector builders in both urban and rural communities. In urban areas, these are mostly existing small building companies, for whom latrines provide a welcome extra market sector. In rural areas, through the NRSP programme, members of the community were trained as latrine builders, and most took up latrine building as either their full or part-time jobs. Therefore, these skills translated into a direct economic incentive to promote improved sanitation. The private sector is only involved in FS collection and haulage while the operation and maintenance of facilities (public toilets, sewerage systems, treatments systems for FS and sewage) including the collection of user charges are the responsibility of the WUC. It is the responsibility of the user to ensure cleanliness of the facility and that before emptying, the sludge is wet enough to allow easy suction.

The private sector in Botswana has not yet found value in FSM. According to [36] the sale of treated FS can generate US\$ 15 per ton TS (Total Solids) and that if treated faecal sludge is reused as organic fertilizer rather than disposed of in landfills, it will save landfill cost amounts to about US\$ 32 per ton TS. The La$\mathrm{DePa}$ machine manufactured by Ethikwini Municipality can provide WUC or the private sector with an opportunity for Business while improving yields for farmers. Therefore, the existing infrastructure developments in the sanitation and wastewater sector do not entail aspects of cost recovery despite the huge subsidies from government [37].

There is a disparity between the service costs by private companies and service costs for WUC. Figure 10 shows that private companies service (emptying) cost are about 10 times greater than WUC emptying costs. This disparity is probably the course of WUC's lack of interest in the type of service.

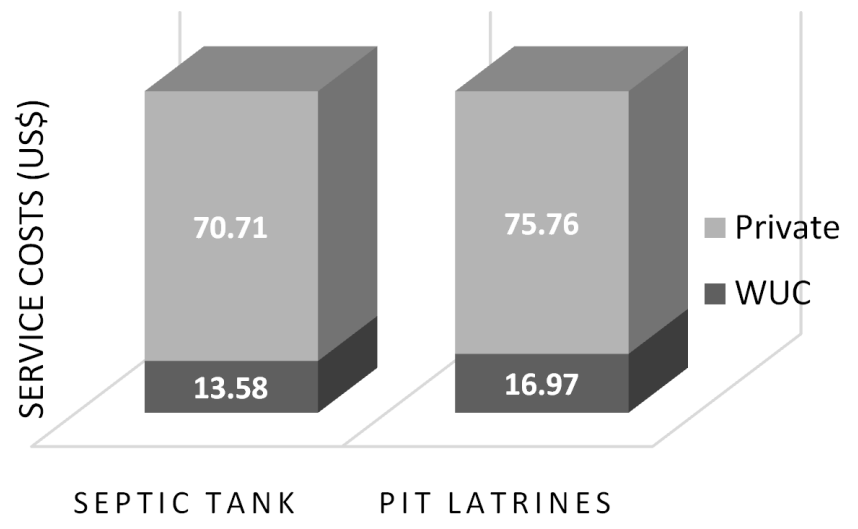

Figure 10. Comparison of public (WUC) and private sector emptying cost for septic tanks and pit latrines. 


\subsection{Regulation and Policies}

Policies and regulations that are relevant to sludge management are discussed below and listed in Table 1. Although these policies are sanitation related, they hardly address problems of FSM in Botswana.

Therefore, FSM is usually embedded in other policies as described below; National Wastewater and Sanitation Policy (2001), is committed to achieving the goals of Agenda 21, which calls for sustainable and environmentally sound development and seeks to preserve, protect and improve the quality of the environment. It also contributes towards protecting public health; as well as ensures a prudent and rational utilisation of natural resources. The policy however, embraces and acknowledges the need for cost recovery to ensure sustainability of sanitation.

The Waste Management Act of 1998 is the main legislation that expressly deals with management of waste. The main purpose of the act is to ensure proper waste management practices from handling to transferring of controlled waste. The act stipulates that waste produced by any establishment has to be classified and transported by registered and licensed waste carrier. Hence, the provisions of this Act must strictly be adhered to for compliance. According to the act, Illegal disposal attract a penalty of fine not exceeding P14,000.00 or to imprisonment for a tem not exceeding 10 years or to both. However, the act is difficult to enact due to lack of institutional capacity. The Public Health Act (PHA) (1981) is used to regulate sanitation to make provisions for public health. This Act, used in conjunction with the Waste Management Act, ensures that waste is controlled such that it does not endanger public health. The purpose and the intent of the Act is to regulate all hazards, risks and nuisances that could

Table 1. Existing legislation and regulations addressing FSM in Botswana.

\begin{tabular}{|c|c|c|c|}
\hline \multirow{2}{*}{ Policy } & \multicolumn{3}{|r|}{ Policy Description and Purpose } \\
\hline & Date & Enforcer & Purpose \\
\hline Building Control Act & 2007 & Councils & $\begin{array}{l}\text { Approves design plans and sanitation facilities (Pit latrines design and } \\
\text { construction). Under review. }\end{array}$ \\
\hline Bye-Laws & $\mathrm{a}$ & Councils & $\begin{array}{l}\text { Requires Plot Owner has to provide proper and sufficient latrine } \\
\text { accommodation and also Require council to prohibit the use of a latrine } \\
\text { that has become a nuisance or a danger to public health. }\end{array}$ \\
\hline $\begin{array}{l}\text { Waste Management } \\
\text { Act }\end{array}$ & 1998 & DWMPC/Councils & $\begin{array}{l}\text { Ensures proper waste management practices from handling to } \\
\text { transferring of controlled waste. }\end{array}$ \\
\hline $\begin{array}{l}\text { National Wastewater } \\
\text { and Sanitation Policy }\end{array}$ & 2001 & DWMPC & $\begin{array}{l}\text { Committed to achieving the goals of Agenda } 21 \text { which seeks to preserve, } \\
\text { protect and improve the quality of the environment. }\end{array}$ \\
\hline Public Health Act & 1981 & $\mathrm{MoH}(\mathrm{DEH})$ & $\begin{array}{l}\text { Its purpose is to promote the personal health and environmental health } \\
\text { within Botswana. It also Approves and coordinates all on-site sanitation } \\
\text { activities within their areas of jurisdiction. }\end{array}$ \\
\hline $\begin{array}{l}\text { Environmental Impact } \\
\text { Assessment Act }\end{array}$ & 1995 & DEA & $\begin{array}{l}\text { The Act Approves major projects and enforces the act (not very useful in } \\
\text { households) for the protection of the environment. }\end{array}$ \\
\hline
\end{tabular}

a. Various Types of Bye Laws. 
be detrimental to the health of Botswana Public it makes very general provisions and its being enacted as an overarching Act in as far as Public Health is concerned. The PHA advocates for cleanliness and safety in built up areas. Pit latrine construction alone is not sufficient to eliminate the faecal threat, the latrine/pit contents or so-called FS have to be disposed of appropriately and treated adequately to safeguard public health and the environment. Therefore, the department of environmental health in the Ministry of Health uses this act to ensure that on-site sanitation facilities do not affect animal and human health. The complexity of the environmental effect of sludge on human health leads to scientific uncertainty and makes sludge disposal difficult [38].

The Building Control Act (2007) requires that, the minimum volume of a new pit shall be at least 10 cubic metres to service a maximum of 8 habitable rooms, provided that where ground conditions prevent such volumes being achieved, the approving authority may vary the size of pits and number and type of latrines to be provided. The act also requires that, An existing pit latrine may be upgraded to a standard pit latrine with the addition of an impermeable top slab, and vent pipe; provided that, in the opinion of the approving authority, the receiving pit has adequate volume and the walls are stable. The Environmental Impact Assessment legislation (1995) has been in place since 2005. The relevance of this policy to sanitation is limited to construction of treatment and disposal facilities such as sludge drying basins and landfills.

\section{Conclusion}

There is evidently no clear working relationship among stakeholders to adequately manage faecal sludge. Although there are policies related to sanitation, there is no clear strategy addressing FSM with regard to pit emptying. Without the community understanding the value of FSM, reuse FS cannot be fully achieved. For better understanding of the behaviour of FS in the VIP latrines, a thorough characterisation of pit latrine sludge should be done in order to improve pit-emptying devices and also to decide on the appropriate designs of the emptying technologies. FSM goals can only be adequately achieved if a vigorous and targeted community and private sector education on the same can be put into place. At the same time government must develop more specific sludge management policy or strategy that emphasizes on pit emptying and transportation with treatment facilities in mind. New technologies for sludge treatment and processing must be considered and introduced as part of the FMS strategy to add value to the FSM process. Poor coordination among stakeholders renders the sanitation sector difficult to manage. WUC should involve and engage stakeholders such as households as well as representatives from the communities, key faecal sludge management stakeholders (such as local authorities, emptier companies, transporters (SME), relevant government authorities and sanitation experts). While BPWSM acknowledges cost recovery in sanitation matters, very little is done to realise this principle. In order to consider resource recovery during FSM, a new FSM model 
is needed in Botswana to turn around the sanitation sector. Promotion of Resource Recovery and Reuse (RRR) of FS can go a long way in avoiding long distance travel by vacuum tankers to the WWTP. Therefore, decentralisation of service may be achieved by construction of planted drying beds (PDBs) as transfer station before, also sometimes referred to as planted dewatering beds, and sludge drying reed beds. To manage FS in a more sustainable manner, WUC has to start taking FS as a resource rather than waste with cost recovery in mind.

\section{Acknowledgements}

This work was made possible through the generous support of The Water Research Commission (SA) and the Bill \& Melinda Gates Foundation (KSA11:K5/2297/11). The authors extend their gratitude to Water Utilities Corporation (WUC) all stakeholders who participated in the workshops. Special thanks go to Ditebogo Nage and Able Keitseng for the assistance they offered in this project. The authors also appreciate staff of the DWMPC for their comments and invaluable discussions.

\section{References}

[1] Gbodi, T.A., Nwude, N., Aliu, Y.O. and Ikediobi, C.O. (1986) The Mycoflora and Some Mycotoxins Found in Acha (Digitaria Exilis Stapf) in Plateau State, Nigeria. Food and Chemical Toxicology, 24, 339-342. https://doi.org/10.1016/0278-6915(86)90012-8

[2] Lewis, W., Farr, J. and Foster, S. (1980) The Pollution Hazard to Village Water Supplies in Eastern Botswana. Proceedings of the Institution of Civil Engineers, 69, 281-293. https://doi.org/10.1680/iicep.1980.2538

[3] Nkotagu, H. (1996) Origins of High Nitrate in Groundwater in Tanzania. Journal of African Earth Sciences, 22, 471-478. https://doi.org/10.1016/0899-5362(96)00021-8

[4] Reed, R. (1994) Why Pit Latrines Fail: Some Environmental Factors. Waterlines, 13, 5-7. https://doi.org/10.3362/0262-8104.1994.036

[5] R. Templeton, M., S. Hammoud, A., P. Butler, A., Braun, L., Foucher, J.-A., Patrice Jourda, J. (2015). Nitrate Pollution of Groundwater by Pit Latrines in Developing Countries. AIMS Environmental Science, 2, 302-313. https://doi.org/10.3934/environsci.2015.2.302

[6] Still, D. (2002) After the Pit Latrine Is Full... What Then? Effective Options for Pit Latrine Management. Biennial Conference of the Water Institute of Southern Africa, Durban, 19-23 May 2002.

[7] Nakagiri, A., Niwagaba, C.B., Nyenje, P.M., Kulabako, R.N., Tumuhairwe, J.B. and Kansiime, F. (2015) Are Pit Latrines in Urban Areas of Sub-Saharan Africa Performing? A Review of Usage, Filling, Insects and Odour Nuisances. BMC Public Health, 16, 120. https://doi.org/10.1186/s12889-016-2772-Z

[8] Statistics Botswana (2011) Botswana Statistical Year Book 2010. Department of Printing and Publishing Services, Gaborone, Botswana.

[9] Acquah, B., Kapunda, S., Legwegoh, A., Gwebu, T., Modie-Moroka, T., Gobotswang, K. and Mosha, A. (2013) The State of Food Insecurity in Gaborone, Botswana. AFSUN Food Security Series 17.

http://www.afsun.org/wp-content/uploads/2016/06/AFSUN17.pdf 
[10] World Bank (2007) Mellenium Development Goals: Confronting the Challenges of Genda Equality and Fragile States. Global Monitoring Report. http://dx.doi.org/10.1596/978-0-8213-6975-3

[11] WHO \& UNICEF (2013) Progress on Drinking Water and Sanitation. Joint Water Supply and Sanitation Monitoring Programme.

[12] Bakare, B., Nwaneri, C., Foxon, K., Brouckaert, C., Still, D. and Buckley, C. (2010) Pit Latrine Additives: Laboratory and Field Trials. Proceedings WISA Biennial Conference \& Exhibition, Durban, 18-22 April 2010.

[13] Banerjee, S.G. and Morella, E. (2011) Africa's Water and Sanitation Infrastructure: Access, Affordability, and Alternatives. Background Paper No. 60864, Africa Infrastructure Country Diagnostic (AICD) World Bank, Washington DC. https://doi.org/10.1596/978-0-8213-8457-2

[14] Jackson, B.M. (1998) Are We Exagerating the Dangers of Groundwater Pollution from On-Site Sanitation Systems Such as Pit Latrines? Borehole Water Journal, 40, 18-21.

[15] Jacks, G., Sefe, F., Carling, M., Hammar, M. and Letsamao, P. (1999) Tentative Nitrogen Budget for Pit Latrines-Eastern Botswana. Environmental Geology, 38, 199-203. https://doi.org/10.1007/s002540050415

[16] World Bank (2009) Republic of Botswana Technical Assistance for Reform of the Water and Sanitation Sector. Final Report.

[17] Bakare, B., Foxon, K., Brouckaert, C. and Buckley, C. (2012) Variation in VIP Latrine Sludge Contents. Water SA, 38, 479-486. https://doi.org/10.4314/wsa.v38i4.2

[18] Mara, D. (1996) Low-Cost Urban Sanitation. John Wiley \& Sons, Hoboken.

[19] Strauss, M. and Montangero, A. (2002) Faecal Sludge Management-Review of Practices, Problems and Initiatives.

[20] Still, D., Salisbury, R., Foxon, K., Buckley, C. and Bhagwan, J. (2010) The Challenges of Dealing with Full VIP Latrines. Proceedings WISA Biennial Conference \& Exhibition, Durban, 18-22 Apri 2010.

[21] Pickford, J. (1997) Technical Brief No. 54: Emptying Pit Latrines. Waterlines, 16, 15-18. https://doi.org/10.3362/0262-8104.1997.044

[22] Van Nostrand, J., Wilson, J.G., UNDP and Technical Advisory Group (TAG) (1983) The Ventilated Improved Double Pit Latrine: A Construction Manual for Botswana. Technical Advisory Group Technical Note No. 3, World Bank, Washington DC. http://documents.worldbank.org/curated/en/392701468769776606/

[23] Thye, Y.P., Templeton, M.R. and Ali, M. (2011) A Critical Review of Technologies for Pit Latrine Emptying in Developing Countries. Critical Reviews in Environmental Science and Technology, 41, 1793-1819. https://doi.org/10.1080/10643389.2010.481593

[24] van Ryneveld, M. and Fourie, A. (1997) A Strategy for Evaluating the Environmental Impact of On-Site Sanitation Systems. Water SA, 23, 279-291.

[25] Tandia, A., Diop, E. and Gaye, C. (1999) Pollution par les nitrates des nappes phréatiques sous environnement semi-urbain non assaini: Example de la nappe de Yeumbeul, Sénégal. Journal of African Earth Sciences, 29, 809-822. https://doi.org/10.1016/S0899-5362(99)00131-1

[26] Vinger, B., Hlophe, M. and Selvaratnam, M. (2012) Relationship between Nitrogenous Pollution of Borehole Waters and Distances Separating Them from Pit Latrines and Fertilized Fields. Life Science Journal, 9, 402-407.

[27] Bassan, M. (2014) Institutional Frameworks for Faecal Sludge Management. In: 
Strande, L., Ronteltap, M. and Brdjanovic, D., Eds., Faecal Sludge Management: Systems Approach for Implementation and Operation, International Water Association, London, 255-272.

[28] Agyei, P.A., Awuah, E. and Oduro-Kwarteng, S. (2011) Faecal Sludge Management in Madina, Ghana. Journal of Applied Technology in Environmental Sanitation, 1, 239-249.

[29] Ngole, V., Otlogetswe, T. and Sisai, M. (2006) The Effect of Ageing on the Fertilizer Value of Sludge from Botswana. Journal of Applied Sciences and Environmental Management, 10, 109-115. https://doi.org/10.4314/jasem.v10i3.17329

[30] Stacey, S., Merrington, G. and McLaughlin, M.J. (2001) The Effect of Aging Biosolids on the Availability of Cadmium and Zinc in Soil. European Journal of Soil Science, 52, 313-321. https://doi.org/10.1046/j.1365-2389.2001.00376.x

[31] Lindsay, B.J. and Logan, T.J. (1998) Field Response of Soil Physical Properties to Sewage Sludge. Journal of Environmental Quality, 27, 534-542. https://doi.org/10.2134/jeq1998.00472425002700030009x

[32] Veeresh, H., Tripathy, S., Chaudhuri, D., Ghosh, B., Hart, B. and Powell, M. (2003) Changes in Physical and Chemical Properties of Three Soil Types in India as a Result of Amendment with Fly Ash and Sewage Sludge. Environmental Earth Sciences, 43, 513-520.

[33] Winkler, M.S., Fuhrimann, S., Pham-Duc, P., Cissé, G., Utzinger, J. and Nguyen-Viet, H. (2017) Assessing Potential Health Impacts of Waste Recovery and Reuse Business Models in Hanoi, Vietnam. International Journal of Public Health, 62, 7-16. https://doi.org/10.1007/s00038-016-0877-x

[34] Schöbitz, L., Zurbrügg, C., Gebauer, H. and Strande, L. (2013) Waste Based Business Models for Recovery. Sandec News. https://www.dora.lib4ri.ch/eawag/islandora/object/eawag:10206

[35] Boot, N. (2008) The Use of Transfer Stations for Faecal Sludge Management in Accra, Ghana. Waterlines, 27, 71-81. https://doi.org/10.3362/1756-3488.2008.007

[36] Steiner, M., Montangero, A., Koné, D. and Strauss, M. (2002) Economic Aspects of Low-Cost Faecal Sludge Management. Estimation of Collection, Haulage, Treatment and Disposal/Reuse Cost. EAWAG/SANDEC, Dübendorf.

[37] Bolaane, B. and Ikgopoleng, H. (2011) Cost Recovery in Waterborne Sanitation: Cases in Botswana. Proceedings of the Institution of Civil Engineers-Engineering Sustainability, 164, 275-286. https://doi.org/10.1680/ensu.2011.164.4.275

[38] Vesilind, P. (2000) Sludge Disposal: Ethics and Expediency. Water Science and Technology, 42, 1-5. 